\title{
- ermitão manoel correa, a IGREJa de nOSSA senHora do DESTERRO E O CAMPO RELIGIOSO DO RIO dE JANEIRO NO PERÍODO COLONIAL
}

The hermit Manuel Correa, the Church of Our Lady of Desterro and the religious field of Rio de Janeiro in the colonial period
William de Souza

MARTINS

(D) williamsmartins@uol.com.br

Universidade Federal do

Rio de Janeiro

Rio de Janeiro, RJ, Brasil

\section{RESUMO}

O artigo pretende analisar a trajetória do ermitão Manoel Correa, responsável pela manutenção da ermida de Nossa Senhora do Desterro, na cidade do Rio de Janeiro, nas últimas décadas do século XVII e princípios do século XVIII. O texto desenvolve três objetivos: ajudar a suprir a lacuna existente na historiografia a respeito de uma forma de vida religiosa pouco conhecida na América Portuguesa; mostrar como, por meio da coleta de esmolas, o ermitão alcançou projeção socioeconômica como administrador de imóveis urbanos e rurais, levando-o a adotar práticas devocionais próximas das elites coloniais; por fim, quando se analisam os conflitos envolvidos na execução do testamento de Manoel Correa, mostrar que havia indefinição sobre o estatuto do ermitão, ora aproximado dos devotos leigos, ora do clero.

Palavras-chave: Eremitas e eremitérios, esmolas, testamentos.

\begin{abstract}
The article intends to analyze the path of Manoel Correa hermit, responsible for the maintaining of Nossa Senhora do Desterro church, in Rio de Janeiro city, in the last decades of the 17 th century and begins of 18th century. The text develops three objectives: help to suply the blank that exists in historiography about a religious lifestyle poorly known in Portuguese America; show how through the alms collecting, the hermit reached socioeconomic projection as a administrator of urban and rural properties, leading him to adopt nearby devotional practices of the colonial elites; and finally, when analyzing the conflicts involved in the will's execution of Manoel Correa, to show there was no definition about the hermit's status, sometimes approximated of laity devoteds, sometimes approximated of clergy.
\end{abstract}

Keywords: Hermits and hermitages, alms, wills. 


\section{Introdução}

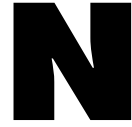

o testamento em vigor, quando veio a falecer no Rio de Janeiro, em 1716, Manoel Correa, natural do lugar do Graial, termo da Vila de Sermancelha do Bispado de Lamego, escolheu em primeiro lugar como testamenteiros os padres carmelitas descalços. Não possuindo herdeiros forçados, instituiu Nossa Senhora do Desterro "por minha universal herdeira de todos os bens declarados, móveis da casa, prata e ouro, dinheiro e tudo o mais que se achar por meu falecimento". ${ }^{1}$ Os bens, conforme será discutido mais adiante, eram muito numerosos e tinham sido adquiridos pelo testador

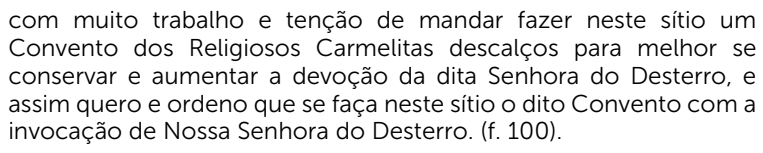

Talvez prevendo futuras dificuldades no cumprimento das disposições testamentárias, Manoel Correa deixou instruções detalhadas aos testamenteiros para a concretização das suas últimas vontades, declarando que se no tempo de seu falecimento "não tiver ainda dado princípio ao dito Convento, nem houver ainda licença de Sua Majestade, os ditos meus testamenteiros conservarão todos os meus bens, [...] e outrem se não poderá intrometer nos ditos" (f. 100). De modo análogo, procurou esclarecer as condições em que havia amealhado o patrimônio que declarava possuir, insistindo que tinha sido necessário "muito trabalho" pessoal para adquiri-lo. Afirmava que os bens não foram comprados com esmolas deixadas por fiéis: "suposto algumas vezes pedisse nesta Cidade em os meus princípios, era para meu sustento, e há 50 anos que não peço esmola e quando pedia era uma vez só na semana aos sábados, e assim todos os ditos bens são meus". (f. 100).

Fora a menção indireta de que já havia pedido esmolas no Rio de Janeiro, não há qualquer menção no corpo do testamento à atividade de ermitão exercida por Manoel Correa. Essa referência só aparece no termo de aprovação do instrumento jurídico, com data de 19 de julho de 1716. Nessa ocasião, o tabelião Vicente de Andrade se dirigiu ao sítio de Nossa Senhora do Desterro, "nas casas aonde mora o Ermitão da dita Igreja Manoel Correa", encontrando-o "de pé, sem doença, e com todo o seu perfeito juízo e entendimento" (f. 100), condições necessárias para a validade das últimas vontades.

O primeiro contato com a documentação das atividades do ermitão de Nossa Senhora do Desterro ocorreu quando tentava mapear a ação dos frades carmelitas descalços no Rio de Janeiro, sob cuja direção espiritual atuaria, décadas mais tarde, a beata Jacinta de São José (MARTINS, 2012, p. 70-72). Na referida ocasião, estava mais preocupado em compreender as alianças construídas entre os devotos leigos e o clero regular, para a finalidade da fundação de novos conventos ou hospícios. ${ }^{2}$ A receptividade mostrada pelos moradores do Rio de Janeiro aos frades carmelitas descalços, que se achavam em 
missão na cidade na década de 1710, pode explicar talvez a doação efetuada aos referidos religiosos pelo ermitão Manoel Correa. Na consulta do Conselho Ultramarino de 23 de março de 1716, que tratava da fundação de um convento de carmelitas descalços no Rio de Janeiro, o procurador da Coroa, apesar de acreditar que "se no seu poder e jurisdição coubera tirar do Brasil todos os frades o fizera de boa vontade", considerava exceções os religiosos do Carmelo Descalço e os padres da Companhia de Jesus. E devido à existência de outros estabelecimentos regulares naquela cidade - referindo-se especificamente aos que tinham sido fundados por jesuítas, franciscanos e beneditinos -, considerava mais adequado que a pretendida fundação ocorresse em outra localidade da capitania fluminense, "onde não há conventos" (CALDERÓN, 1971, p. 198). Afastando-se do parecer do procurador da Coroa, três membros do Conselho representaram ao soberano a favor da fundação, desde que limitada ao número de 12 religiosos, argumentando que não agravaria

A Fazenda de Vossa Majestade a edificação deste Convento, pois se oferece a fazê-lo um ermitão constituindo-lhe renda para sua sustentação [...] nem também aos povos em havê-lo, pois que naquela praça não há mais que unicamente um convento de religiosos de São Francisco, mendicantes, não lhe pode ser esta nova fundação de grande encargo, principalmente estando esta hoje tão rica pelo grande comércio que tem e riquezas que recebe das minas. (CALDERÓN, 1971, p. 198, grifos meus).

A resolução do soberano, com data de 30 de março de 1716, conformava-se com o parecer dos três conselheiros. Não obstante, o cumprimento da vontade régia não pôde se efetivar de imediato, devido aos problemas decorrentes da execução do testamento de Manoel Correa. Sem detalhar por enquanto este ponto, deve-se sublinhar que a documentação revela que o plano do ermitão em favorecer os religiosos carmelitas descalços chegara, na Bahia, em 1714, ao conhecimento do vice-rei Marquês de Angeja. Assim, o apoio desta e, possivelmente, de outras autoridades coloniais, ocorrera pelo menos dois anos antes da elaboração do testamento e falecimento do ermitão. (CALDERÓN, 1971, p. 196-199).

Afora as esmolas e benefícios que deixou aos frades carmelitas no testamento, não foi possivel identificar outros elementos que aproximassem o ermitão Manoel Correa à devoção do Carmelo. Uma questão interessante apontada pelos historiadores da Ordem do Carmo se encontra na possível origem eremítica da instituição. Dando continuidade a relatos presentes em cronistas da Ordem do século XVIII e de períodos anteriores, aqueles estudiosos apontaram para a formação da Ordem do Carmo no atual território da Palestina, quando grupos de eremitas que viviam nas proximidades do Monte Carmelo foram agrupados por Alberto, patriarca de Jerusalém, sob uma mesma regra, entre 1206 e 1214 (SMET, 1987, p. 3-16; VELASCO BAYÓN, 2001, p. 15-24). Quanto à atuação dos ermitãos nas áreas de colonização, alguns trabalhos mostram que aqueles agentes não se aproximaram apenas dos religiosos carmelitas, ligando-se a outras ordens regulares. (RUBIAL GARCÍA, 2006; BORGES, 2015).

Uma informação mais interessante diz respeito à atração que o culto de Nossa Senhora do Desterro exerceu na Colônia sobre os religiosos carmelitas. João Fernandes Vieira, uma 
das maiores lideranças luso-brasileiras na resistência aos holandeses na Capitania de Pernambuco, fundou uma capela dedicada à Senhora do Desterro em cumprimento de uma promessa alcançada nas batalhas. Em 1689, a capela já se encontrava construída, e naquele ano foi ali sepultada sua mulher, D. Maria César, "com o hábito de Santa Teresa", um possível indício de devoção à Santa fundadora dos carmelitas descalços. Desde 1686, esses religiosos já se encontravam em Pernambuco, onde haviam obtido a mercê para edificarem um convento na capela do Desterro, que lhes fora doada por licença do cabido diocesano, confirmada pelo rei D. Pedro II (COSTA, 1976, p. 171-172). Em 1663, Antônio de Araújo e Francisco Rodrigues Braga, intitulando-se padroeiro da ermida do Desterro da cidade da Bahia, solicitaram ao rei D. Afonso VI autorização para fundarem naquela capela um hospício ou convento de religiosos carmelitas descalços. Não obstante, o templo acabou sendo usado para instalar um convento de religiosas clarissas. Os carmelitas descalços tiveram que esperar até 1697 para inaugurarem uma sede na Bahia. (CALDERÓN, 1971, p. 13-29).

Além das questões tocantes à fundação de estabelecimentos regulares, a documentação referente ao ermitão Manoel Correa permite lançar luz sobre uma forma de vida religiosa ainda pouco estudada na América Portuguesa. Antes de avançar este ponto, parece oportuno mencionar a distinção conceitual, apresentada por um estudioso português, entre as figuras do eremita e do ermitão (CARVALHO, 2002, p. 84-85). O primeiro se caracteriza pela prática do ascetismo e da anacorese - a fuga do mundo em busca de uma vida contemplativa -, um tipo de experiência religiosa que remonta aos primeiros tempos do Cristianismo e que se estendeu por toda a Idade Média, períodos cuja análise escapa a este estudo (LACARRIÈRE, 2002, p. 18). Já o ermitão, que podia ser de condição leiga ou eclesiástica, e também a ermitoa, eram homens e mulheres que, "mais ou menos transitoriamente, se encarregaram da manutenção litúrgica e conservação fabriqueira da eremita em que, em princípio, sob licença de autoridade episcopal, viviam e, mesmo assim, nem sempre obrigatoriamente" (CARVALHO, 2002, p. 84). Não obstante, o léxico da época não acentua tanto as diferenças entre o eremita e o ermitão. Segundo Raphael Bluteau, a primeira palavra quer dizer o "habitador de Ermo, ou lugar solitário", enquanto que o "ermitam" designa "o homem apartado do mundo e retirado para o campo, para viver solitariamente e tratar da sua salvação" (BLUTEAU, 1713, v. 3, p. 188-189, grifos do autor). Na documentação acerca de Manoel Correa, as palavras se tornam ainda mais incertas, pois se é referido com mais frequência como "ermitão", por vezes é designado como "eremitão" (f. 76-77), termo não dicionarizado, e que constitui possivelmente uma corruptela da primeira palavra. Atuando isoladamente ou associando-se a irmandades, os ermitãos tornavam-se frequentemente responsáveis pela manutenção de sedes de culto religioso, por meio da arrecadação de esmolas junto aos fiéis.

No que diz respeito ao Período Moderno, a historiografia que trata de Portugal e da América ibérica concedeu maior atenção ao eremitismo no sentido mais estrito, constituído pela primeira acepção analisada acima (CARVALHO, 2002, p. 83-145; BORGES, 2011, p. 189-206). Para a região da Nova Espanha, ganha destaque o estudo que Antonio Rubial 
García dedicou aos ermitãos leigos que viviam isoladamente, assim como às mulheres conhecidas como beatas. A abordagem do autor certamente se aproxima do e inspira o recorte analítico seguido em minhas próprias pesquisas, a partir das quais as beatas e os ermitãos/eremitas são vistos em um lugar particularmente sensível do campo religioso, ora se aproximando do modo de vida e dos modelos de santidade próprios das ordens regulares, ora sendo perseguidos e punidos pelos agentes eclesiásticos. ${ }^{3} \mathrm{O}$ referido contraste tem a sua razão de ser na própria ambiguidade da situação jurídica do ermitão, conforme será visto nos conflitos sobre a execução do testamento de Manoel Correa. A partir do processo de controle e disciplinamento analisado por Rubial García na Nova Espanha, é possível compreender algumas nuances presentes nos termos eremita e ermitão. No Concílio Mexicano de 1585, proibiu-se a presença de pessoas que levavam um modo de vida isolado, forçando a entrada de tais eremitas nas ordens regulares constituídas. "Em Nueva España los anacoretas de los siglos XVI y XVII se convirtieron em santeros y custódios de ermitãs em el XVIII. La institución había conseguido asimilarlos y volverlos parte del sistema" (RUBIAL GARCÍA, 2006, p. 29). ${ }^{4}$ Assim, a crer na análise do autor citado, por meio de um processo de clericalização inspirado nas diretrizes do Concílio de Trento, os eremitas anacoretas que viviam isoladamente na Nova Espanha foram enquadrados nas estruturas eclesiásticas, ora incorporando-se nas ordens regulares, ora tornando-se ermitãos, de condição leiga ou eclesiástica, responsáveis pela manutenção de sedes de culto divino. ${ }^{5}$

Existem dois aspectos relacionados ao modo de vida de eremitas e ermitãos que exigem maior reflexão, por terem sido abordados pela historiografia: a questão do isolamento e a do sedentarismo/mobilidade. Conforme já salientado por um estudioso português, o isolamento do mundo característico da vida eremítica não deve ser visto de modo tão acentuado. Por vezes, o locus em que habitava o eremita em Portugal em princípios da Época Moderna não era particularmente áspero ou solitário,

pois muitos deles estavam, como era quase de tradição e o exigia
a logística da sobrevivência material e espiritual, relativamente
próximos de povoados e cidades e ao amparo de conventos, mas
a uma distância que nitidamente os separava do mundo, encarnado
tantas vezes - e quase sempre negativamente - na "urbe".
(CARVALHO, 2002, p. 109).

Na Nova Espanha ocorria uma situação semelhante. Em vez dos bosques e das covas próprias da tradição hagiográfica do eremus medieval, "lo más general era que estos 'solitarios' pasaran mucho tiempo en las ciudades, em casa de algún amigo y, salvo raras excepciones, no buscavan para vivir espacios demasiado alejados de los grandes y medianos núcleos urbanos". (RUBIAL GARCÍA, 2006, p. 23).

No âmbito da América Portuguesa, refletindo sobre as atividades de certos ermitãos na capitania das Minas, um autor encontrou uma fórmula sintética para caracterizar a posição intermediária dos referidos agentes religiosos: "o ermitão não está nem radicalmente apartado nem radicalmente inserido no mundo. Seus espaços privilegiados são, antes, os interstícios do mundo". O mesmo historiador citado completa: "a despeito da genealogia 
das palavras 'ermitão', 'ermida', 'ermo' (do grego éremos: deserto, solidão, isolamento), o ermitão não pode se furtar a um contato, por fugaz que seja, com os homens. Sem estes, como aportar recursos a sua capela, ao seu santuário?" (MATA, 2010, p. 41, grifos do autor). Sem dúvida, a caracterização delineada pelos autores citados se aplica aos dois casos mais documentados de ermitãos atuantes na cidade do Rio de Janeiro durante o período colonial: o próprio Manoel Correa, ermitão de Nossa Senhora do Desterro, e Antônio Caminha, o ermitão do templo de Nossa Senhora da Glória do Outeiro, como será ainda analisado.

No que diz respeito à questão da mobilidade/sedentarismo, Rubial García descreve, para os séculos XVI e XVII, um quadro de contínua mobilidade dos eremitas/ermitãos na Nova Espanha. Não só mudavam de habitação, pois "junto con las limosnas que recebían por su labor religiosa, estos personajes se mantenían gracias al ejercicio de ofícios esporádicos: pastor, labrador, enfermeiro, barbeiro, hortelano, vendedor ambulante", entre outras ocupações (RUBIAL GARCÍA, 2006, p. 23). No que tange à América Portuguesa, os casos já estudados pela historiografia e a trajetória particular do ermitão Manoel Correa permitem afirmar que, ainda que os ermitãos percorressem grandes distâncias em busca de esmolas, retornavam quase sempre à ermida de que cuidavam. No que tange à realização de ofícios esporádicos, tal aspecto se aplica ao ermitão de Nossa Senhora do Desterro, como será visto ainda em detalhes.

Para a capitania das Minas, o exemplo mais bem-estudado de vida eremítica é constituído por Lourenço de Nossa Senhora, fundador de um eremitério na Serra do Caraça em fins do século XVIII. Na trajetória desse irmão da Ordem Terceira de São Francisco, torna-se patente a influência exercida por modelos de devoção oriundos da família franciscana: tinha sido esmoler da Terra Santa e expressou em 1802 a intenção de introduzir missionários franciscanos varatojanos, arrábidos ou brancanos, cujos conventos representavam o ideal de vida reformada dentro da Ordem dos frades menores em Portugal. Antes da referida iniciativa, chegou a reunir no eremitério do Caraça vários irmãos terceiros franciscanos que compartilhavam seu modo de vida. (BORGES, 2015, p. 397-414).

Tendo apresentado um panorama de elementos necessários à contextualização da vida eremítica e das atividades de ermitãos no mundo ibérico e colonial, o foco será dirigido agora à documentação específica que trata do ermitão Manoel Correa. A análise será dividida em duas partes. Em primeiro lugar, será discutida a tarefa principal do ermitão, isto é, a arrecadação de esmolas. Relacionada à referida tarefa, será também analisado o patrimônio imobiliário acumulado pelo ermitão em nome de Nossa Senhora do Desterro do Rio de Janeiro. Em seguida, serão vistos os conflitos envolvendo a execução e a validade do testamento de Manoel Correa. Sem dúvida, o caráter expressivo das doações e do patrimônio acumulado pelo ermitão impulsionou a ação tanto dos representantes do bispado fluminense quanto das autoridades da Coroa no duro litígio que se seguiu à morte de Manoel Correa. 


\section{Esmolas e rendimentos para Nossa Senhora do Desterro}

No Rio de Janeiro, as atividades de Manoel Correa foram pouquíssimo analisadas, ainda que haja registro delas em cronistas coloniais. Apesar de sua importância para a consolidação do patrimônio da capela de Nossa Senhora do Desterro, o referido ermitão não tinha sido seu fundador. Frei Agostinho de Santa Maria, na sua famosa obra, atribui a fundação a Antonio Gomes do Desterro, o qual, "pela grande devoção que tinha para este título, que também o tinha por apelido, lho dedicou, e a fazenda ou quinta em que o fundou quis que para sempre fosse da Senhora". Os rendimentos dos bens doados deveriam ser aplicados "à fábrica da Casa da Senhora e ornato do seu culto, como para sustento do Ermitão, que havia de ter cuidado da Casa e dos ornamentos e serviço dela" (SANTA MARIA, 2007, p. 18). Não foi possivel confirmar a veracidade dessa informação à luz da documentação reunida nos fundos do Conselho Ultramarino. Antes, tais documentos referem que a provisão de ereção da capela de Nossa Senhora do Desterro do Rio de Janeiro tinha sido passada em 1605 por Mateus da Costa Aborim, "autoridade apostólica, prelado e administrador" do Rio de Janeiro. A referida licença contemplou a petição do padre Luís Arão Rangel, "que tinha grande devoção de edificar uma capela com a invocação de Nossa Senhora do Desterro em o monte junto da Carioca fora desta cidade" (f. 45). Não obstante, há uma discrepância entre o ano em que teria sido passada essa provisão e o período em que Mateus da Costa Aborim ocupou a prelazia do Rio de Janeiro - segundo cronistas e estudiosos das atividades desse prelado, se estendeu entre 1606 e 1629. (ARAÚJO, 1945, v. 2, p. 231; RUBERT, s/d, p. 44-47). ${ }^{6}$

Seja como for, as informações apontam para a existência da capela em princípios do século XVII. Em meados do referido século, parecia atrair certa atenção dos devotos da cidade. Na Vida que Simão de Vasconcelos dedicou ao padre jesuíta João de Almeida, o cronista da Companhia de Jesus narrou que, em 1650, padecera uma febre maligna por espaço de dois meses, que o impedia até de se mover na cama, sem achar remédios em "Sangrias, Purgas, Banhos e Unturas que lhe aplicaram". Foi encontrado nesse estado pelo padre João de Almeida que, em prol do restabelecimento da saúde do confrade, "foi dizer Missa a certa Igreja de Nossa Senhora do Desterro, pouco distante da Cidade". Segundo o cronista da Companhia de Jesus, a intermediação da Virgem se mostrou eficaz, livrando-o das dores e restituindo-lhe os movimentos perdidos (VASCONCELLOS, 1658, p. 191-192). Em princípios do século XVIII, a devoção a Nossa Senhora do Desterro encontrava-se enraizada na cidade, a crer na informação de outro cronista, que assinalava a afluência de fiéis e de ex-votos ao templo:

É esta Santíssima Imagem muito milagrosa, e assim é muito frequentada a sua Casa de romagens, aonde vão muitas pessoas devotas, a fazer-lhe as suas Novenas; para o que tem casas, aonde se possam recolher e assistir os seus romeiros em todo o tempo, em que fazem as Novenas [...]. Os milagres, que continuamente obra, são inumeráveis, como o estão experimentando todos continuamente, e o estão testemunhando os muitos sinais e memórias, que se vem pender daquela sua Casa. (SANTA MARIA, 2007, p. 19). 
O ermitão Manoel Correa contribuiu, sem dúvida, para ampliar a devoção a Nossa Senhora do Desterro na cidade de São Sebastião. A documentação enviada ao Conselho Ultramarino reúne listas de esmolas constituídas por dinheiro e objetos materiais diversos remetidos por fiéis. Não é possível dizer se as referidas listas estão completas: em muitas passagens, a leitura da documentação se revela truncada devido à sucessão pouco organizada de traslados de documentos originais. Em muitas passagens, há referência a dádivas recebidas motivadas por promessas feitas a Nossa Senhora do Desterro. A arrecadação dos recursos e bens materiais devia envolver grandes esforços que, à primeira vista, eram realizados em caráter pessoal pelo ermitão. A título de exemplo, nas despesas registradas para o ano de 1673 , encontram-se $2 \$ 000$ réis "por cinco pares de sapatos que gastou o Ermitão". No ano assinalado, foram dispendidos 400 réis para a compra "de uma caixinha que mandou fazer para pedir esmola". Por fim, há o registro de despesa feita para o seu próprio traje: "de um hábito que fez para trazer de estamenha", $11 \$ 720$ réis (f. 67). As contas do ermitão receberam a fiscalização das autoridades diocesanas em duas ocasiões. ${ }^{7}$

As anotações contendo registros de esmolas se estendem entre os anos de 1673 e 1682. As coletas feitas na cidade para arrecadar dinheiro são registradas mês a mês, separando-se destas as quantias apuradas na quinta-feira da Semana Santa. Naquele primeiro ano, Manoel Correa conseguiu arrecadar $51 \$ 860$ réis nos peditórios de esmolas pela cidade. Desta soma, $3 \$ 300$ réis constituíam esmolas recebidas na quinta-feira maior. A média mensal das contribuições de 1673 foi de aproximadamente 4 \$047 réis. No mesmo ano de 1673, além das quantias descritas, Manoel Correa arrecadou mais vinte mil réis, referentes a esmolas coletadas no recôncavo da cidade do Rio de Janeiro, constituídas por "galinhas, ovos e dinheiro". Finalmente, tinham sido também recebidas 78 arrobas de açúcar branco, cotado a 900 réis por arroba, perfazendo a quantia de $70 \$ 200$ réis. O total apurado pelo ermitão em 1673 foi de pouco mais de 140 mil réis. O quadro 1 mostra, dentro do período assinalado, os recebimentos anuais das esmolas e as despesas efetuadas.

A mesma organização contábil de divisão entre esmolas arrecadadas em dinheiro na cidade, esmolas em dinheiro e outros produtos coletados no recôncavo e esmolas constituídas por arrobas de açúcar é adotada nos anos posteriores, e seria muito descritivo retomar aqui todos os registros. Dito isto, dois aspectos podem ser explorados mais profundamente nas contas do ermitão: as esmolas feitas nominalmente por alguns fiéis e as diligências empreendidas por Manoel Correa para aplicar os recursos devocionais. No que diz respeito ao primeiro ponto, por exemplo, no ano de 1674 aparecem indicações individuais de esmolas dadas em dinheiro, totalizando quatro devotos. Foi o caso de Pedro de Souza Pereira, que contribuiu com dez mil réis, e de "um homem de Angola", que doou dois mil réis. Outras contribuições em dinheiro eram destinadas à aquisição de alfaias para o culto divino. Assim, nove mil réis foram dados por devotos para a aquisição de um bordão de prata para o Menino Jesus. Por sua vez, Manoel Rodrigues fez doação de um púcaro de prata, que foi avaliado em seis mil réis (f. 62). Anotadas separadamente, constam as esmolas que, no espaço de oito anos, foram deixadas por alguns defuntos a Nossa Senhora do 
Quadro 1 - Esmolas para Nossa Senhora do Desterro e despesas efetuadas pelo ermitão Manoel Correa (1673-1682)

\begin{tabular}{ccc}
\hline Ano & Esmolas (réis) & Despesas (réis) \\
\hline 1673 & $142 \$ 060 * / 174 \$ 380$ & $174 \$ 380$ \\
1674 & $209 \$ 600 * / 234 \$ 770$ & $234 \$ 770$ \\
1675 & $134 \$ 200 * / 138 \$ 300$ & \\
1676 & $140 \$ 100 * / 130 \$ 100$ & \\
1677 & $139 \$ 100 * / 139 \$ 100$ & \\
1678 & $138 \$ 950 * / 128 \$ 950$ & \\
1679 & $154 \$ 250 * / 154 \$ 250$ & \\
1680 & $145 \$ 450 * / 145 \$ 450$ & \\
1681 & $144 \$ 400 * / 144 \$ 400$ & \\
1682 & $143 \$ 500 * / 143 \$ 500$ & \\
\hline
\end{tabular}

Fonte: AHU_ACL_CU_017, cx. 28, d. 2931. 1735, junho 7, Lisboa. Decreto do rei D. João V concedendo licença ao procurador [dos religiosos capuchos da Província da Imaculada Conceição de Nossa Senhora do Rio de Janeiro] para construir um seminário eclesiástico com os rendimentos da capela chamada Nossa Senhora do Desterro, bem como de seus bens (...), f. 62-71. Disponivel em: <http://resgate.bn.br/docreader/DocReader.aspx?bib=017_RJ_AV>. Acesso em: maio 2016.

* Observação: no campo das esmolas, os valores assinalados com asterisco foram apurados a partir da soma de todas as parcelas indicadas nos registros, sem considerar os totais indicados na fonte. Os valores sem asteriscos correspondem aos totais indicados na fonte.

Desterro. É de supor que tais doações tenham sido estipuladas em verbas testamentárias. No referido período, foram contabilizadas doações de quatro fiéis, totalizando $24 \$ 000$ réis. Além desses, Thomé Correa, "governador que foi desta praça", havia prometido trinta mil réis, dos quais $5 \$ 600$ foram efetivamente recebidos pelo ermitão. O ex-governador doara ainda "uma caixa de açúcar para se fazer a festa". (f. 67). ${ }^{8}$

Entre 1673 e 1682, as inúmeras diligências empreendidas pelo ermitão para a promoção do culto de Nossa Senhora do Desterro podem ser assim resumidas: aquisição de alfaias e demais ornamentos de culto para a capela do Desterro; aquisição de telhas, tábuas, pregos e uma infinidade de outros objetos destinados às obras de conservação e melhoramento da mesma capela; envio de dezenas de arrobas e de caixas de açúcar para Lisboa, Porto e llha da Madeira, provavelmente apuradas junto aos fiéis ou produzidas nas terras de Irajá. Este último aspecto sinaliza certa pujança da economia agrária fluminense no período, como também a inserção do ermitão Manoel Correa nas redes comerciais atlânticas, que se revelaram fundamentais à manutenção da sua atividade de culto (SAMPAIO, 2003, p. 113-141; SAMPAIO, 2014, p. 379-418). Por tudo que já foi mostrado, verifica-se que não era inteiramente exata a informação fornecida pelo ermitão em 1716, em seu testamento, segundo a qual fazia meio século que não pedia esmolas. 
Após a morte do ermitão Manoel Correa, o vigário da freguesia de Irajá, o padre licenciado João de Barcelos Machado, recebeu a comissão de inventariar os bens de um capão situado naquela freguesia, que constava no rol de bens de Nossa Senhora do Desterro. ${ }^{9}$ Segundo a escritura de venda de 1678, os referidos chãos do campo de Irajá foram vendidos por cem mil réis a Manoel Correa "para a dita Senhora do Desterro de que é ermitão" (f. 54-55). Assim, ainda no período que praticava peditórios de esmolas, Manoel Correa começou a buscar outras fontes de rendimentos para a manutenção da capela e do culto de Nossa Senhora do Desterro. Possivelmente, a quantia para a aquisição do capão fora obtida com recursos extraídos das esmolas dos fiéis. Não se sabe o ano preciso em que o capão começou a produzir, mas as informações truncadas das contas apontam para o mesmo ano de 1678, encontrando-se os seguintes rendimentos: no primeiro ano de funcionamento, 12@ de açúcar; no segundo, 23@; no terceiro, 41@ e no quarto, 76@, que, avaliadas em 850 réis cada arroba, chegavam a $120 \$ 700$ réis. Assim, no último ano, somente as rendas do capão do Irajá representavam quase a metade das rendas anuais apuradas anteriormente com os peditórios. Nas informações prestadas em 1701 ao visitador diocesano, o doutor Francisco da Silveira Dias, o capão continha "um partido de canas, com 17 peças do gentio da Guiné e três crias, e cem cabeças de gado, entre grande e pequeno" (f. 69). Nas informações mais completas disponíveis no inventário de 1716 , foram registrados 25 cativos que trabalhavam no capão de Irajá, que mantinham entre si diversos vínculos familiares, sem contar sete escravos que viviam com o ermitão na cidade, aplicados ao serviço de Nossa Senhora do Desterro. (f. 52-53).

No que diz respeito à manutenção da capela e, por extensão, do culto de Nossa Senhora do Desterro, o passo seguinte do ermitão Manoel Correa se dirigiu à aquisição de bens de raiz na região central da cidade do Rio de Janeiro. No contexto em questão, as duas últimas décadas do século XVII e as duas primeiras do XVIII, o espaço da urbs era relativamente restrito, limitando-se a um quadrilátero em cujos vértices estavam o Morro do Castelo, onde se situava a primeira matriz e o Colégio dos jesuítas; o Mosteiro de São Bento; o Morro da Conceição, onde se situava a residência episcopal; e o Convento de São Francisco. A estratégia utilizada pelo ermitão não era um procedimento isolado. Antes, diversas instituições religiosas situadas na cidade, como o Mosteiro de São Bento, passaram a investir cada vez mais, na conjuntura assinalada, em imóveis urbanos. (SOUZA, 2014, p. 182-183; FRIDMAN, 1999, p. 62; MARTINS, 2009, p. 159-189).

No inventário de 1716 organizado após a morte do ermitão, encontram-se mencionados oito imóveis na cidade que geravam rendas de aluguéis para Nossa Senhora. Isso sem contar as "casas que servem de agasalhar romeiros", situadas nas proximidades da ermida da Virgem, cujo uso se pautava por uma lógica devocional (f. 123). Duas das referidas propriedades situavam-se na ladeira de e no caminho para Nossa Senhora do Desterro, não se encontrando na documentação suas escrituras. Com relação aos demais imóveis pertencentes ao patrimônio do Desterro, que ocupavam na urbs uma localização mais privilegiada, o quadro 2 descreve as características principais apuradas nas escrituras. 
Quadro 2 - Imóveis urbanos de Nossa Senhora do Desterro (1693-1715)

\begin{tabular}{|c|c|c|c|c|}
\hline Ano & Modo de aquisição & Características & Localização & Valor \\
\hline 1693 & Compra & $\begin{array}{l}\text { Sobrado de pedra e cal } \\
\text { com lojas }\end{array}$ & $\begin{array}{l}\text { Rua Direita, no } \\
\text { canto da Quitanda }\end{array}$ & $800 \$ 000$ réis \\
\hline 1701 & $\begin{array}{l}\text { Doação, com } \\
\text { obrigação de uma } \\
\text { missa semanal } \\
\text { perpétua }\end{array}$ & $\begin{array}{l}\text { Casas terreiras, } \\
\text { construídas depois em } \\
\text { sobrado }\end{array}$ & Rua Direita & \\
\hline 1706 & Compra & Sobrado de pedra e cal & Rua Direita & Quatro mil \\
\hline 1706 & Compra & $\begin{array}{l}\text { Casas terreiras de taipa } \\
\text { de mão }\end{array}$ & Rua de Salvador Luiz & $\begin{array}{l}\text { cruzados, pelas } \\
\text { duas } \\
\text { (1:600\$000 réis) }\end{array}$ \\
\hline 1711 & Compra & $\begin{array}{l}\text { Casinhas de taipa de } \\
\text { mão }\end{array}$ & Rua das Flores & $200 \$ 000$ réis \\
\hline 1715 & Compra & $\begin{array}{l}\text { Casas terreiras, } \\
\text { fronteira de pedra e cal }\end{array}$ & $\begin{array}{l}\text { São Bento, no } \\
\text { canto defronte dos } \\
\text { quartéis }\end{array}$ & $700 \$ 000$ réis \\
\hline
\end{tabular}

Fonte: AHU_ACL_CU_017, cx. 28, d. 2931. 1735, junho 7, Lisboa. Decreto do rei D. João V concedendo licença ao procurador [dos religiosos capuchos da Província da Imaculada Conceição de Nossa Senhora do Rio de Janeiro] para construir um seminário eclesiástico com os rendimentos da capela chamada Nossa Senhora do Desterro, bem como de seus bens (...), f. 62-71. Disponivel em: <http://resgate.bn.br/docreader/DocReader.aspx?bib=017_RJ_AV>. Acesso em: maio 2016.

* Observação: informações sobre as escrituras também se encontram disponíveis no banco de dados da estrutura fundiária do Recôncavo da Guanabara (séculos XVII-XVIII). Ver: <http://mauricioabreu.com.br/escrituras>.

Em 1693, para a aquisição do primeiro sobrado na Rua Direita, a principal da cidade, o ermitão precisou da autorização do vigário-geral, o doutor José Pimenta de Carvalho, deão da Sé do Rio de Janeiro. Manoel Correa obteve a licença "para comprar as casas de que faz menção e pagá-las do dinheiro de Nossa Senhora do Desterro" (f. 59). Nas outras escrituras, não constam autorizações semelhantes. Por sua vez, os bens de raiz que passaram em 1701 ao patrimônio de Nossa Senhora do Desterro foram doados na verba de testamento de Belchior Rodrigues, com a cláusula seguinte:

- Padre Ermitão da dita Ermida será obrigado a mandar dizer por minha alma todos os sábados do ano uma Missa no altar de Nossa Senhora, com declaração que a tal obrigação passará a todos aqueles que sucederem a administrarem a dita Igreja, que creio me não faltarão com esta obrigação, pois eu não falto à promessa que fiz à Senhora quando comprei estas casas de que lhas havia dar. (f. 55).

Além dos imóveis, em sua maior parte comprados por Manoel Correa, o inventário do ermitão trazia a lista de vários recursos a receber de diferentes indivíduos. Há uma escritura, assinada em 1715, mediante a qual o ermitão emprestara a quantia de $166 \$ 400$ réis. Com 
data de 1704, foi possível identificar outra escritura no valor de $450 \$ 000$ réis, em que o ermitão aparecia como credor do coronel Manoel de Barros de Araújo que, como garantia do empréstimo, hipotecara "uma morada de casas de sobrado, de pedra e cal, em que vive, sita ao pé da ladeira de São Bento". ${ }^{10}$ Provavelmente, este último empréstimo havia sido liquidado à época da morte do ermitão, pois não há referência a ele no inventário. O rol dos bens administrados por Manoel Correa inclui ainda: créditos a receber de diferentes indivíduos, no valor de $163 \$ 460$ réis; aluguéis a receber dos imóveis alugados, no valor de $559 \$ 220$ réis; e saldo de contas em Lisboa, no valor de $135 \$ 372$ réis.

No testamento em vigor quando veio a falecer, em 1716, Manoel Correa referiu de modo sucinto os bens materiais, informando números relativamente próximos àqueles existentes no inventário:

Declaro que comprei umas terras a que chamam o capão na freguesia de Irajá, nas quais fiz um curral de gado donde se acham 78 cabeças de gado entre grandes e pequenas. Item: declaro ter comprado dez moradas de casas nesta cidade, fora as deste sítio [do Desterro], e aqui tenho 34 escravos entre pequenos e grandes. Declaro que todos estes bens foram adquiridos por mim com muito trabalho... (f. 100).

A partir do exame dos bens materiais constantes no inventário, no testamento e em outros documentos que fazem referência às atividades de Manoel Correa, pode-se chegar a algumas conclusões. É possível conjecturar que, pouco tempo depois da aquisição do capão de Irajá, o ermitão conseguiu obter recursos que o poupavam dos frequentes peditórios de esmolas na cidade e no recôncavo do Rio de Janeiro. As rendas antes obtidas da caridade pública passavam, cada vez mais, a ser geradas nas atividades de criação de gado e de produção de açúcar. A passagem de uma atividade a outra não ocorreu tão cedo como o ermitão imaginava, isto é, cinquenta anos antes de sua morte, mas ao longo da década de 1680, conforme já foi visto. A referida mudança também deve ter ocorrido de modo gradual, na medida em que as novas rendas não excluíam o recebimento de doações de devotos. Em 1715, um ano antes de sua morte, o ermitão continuava a receber recursos de fiéis, como a esmola de 2a de cera prometida a Nossa Senhora do Desterro pelo sargentomor Gaspar de Brito Soares (f. 127). Não obstante, parece muito provável que essa fonte de recursos havia se tornado menos importante, em comparação à atividade agropastoril. Nos anos seguintes, o ermitão diversificou ainda mais suas atividades, ampliando os recursos aplicados à ermida e ao culto de Nossa Senhora do Desterro mediante rendimentos de aluguéis e empréstimos.

Em certo sentido, Manoel Correa tinha razão em alegar que os bens descritos em seu testamento tinham sido adquiridos com "muito trabalho". Entretanto, apesar do inegável empenho pessoal na administração do patrimônio, parece mais correto dizer que o ermitão adotara o modo de vida da nobreza da terra local, apropriando-se do trabalho alheio do plantel que constituiu na freguesia do Irajá. Outro sinal da adoção do modo de vida das elites coloniais foi o envolvimento do ermitão na atividade de rentista, investindo 
os recursos de Nossa Senhora do Desterro - sejam os auferidos diretamente dos fiéis ou aqueles oriundos do capão do Irajá - na aquisição de imóveis bem-valorizados na cidade e na realização de empréstimos. O referido perfil aproximava o ermitão de camadas sociais situadas nas posições superiores da hierarquia colonial, já bem analisadas pela historiografia. ${ }^{11}$ Sem dúvida, o fato de viver de rendimentos da terra, obtidos com o uso da mão de obra escrava, de aluguéis e de empréstimos devia conferir ao ermitão uma aura de respeitabilidade social que se somava à atração devocional que possivelmente exercia junto a alguns fiéis. Essa imagem a respeito do ermitão Manoel Correa sem dúvida está próxima da apresentada em 1714 por frei Agostinho de Santa Maria, cuja famosa obra foi publicada pouco tempo depois, em 1723:

No tempo presente tem um Ermitão, homem honrado, virtuoso e com muito propósito, a qual há muitos anos que assiste a Senhora, e com o grande amor com que a serve lhe tem aumentado muito a sua Casa, e as suas rendas, porque tem um curral de gado nos campos de Irajá, partido de canas, escravos e tudo em terra própria da Senhora. (SANTA MARIA, 2007, p. 18).

O caso de Manoel Correa revela a utilização de mecanismos de ascensão social por parte de um agente atuante no campo religioso no Antigo Regime dos trópicos. O que parece conferir certa nota de singularidade à trajetória analisada está no fato de que a atividade do ermitão estava, no sentido histórico e semântico, ligada a práticas de ascetismo. Ainda que, a rigor, não haja indícios que permitam aproximar Manoel Correa a formas rigorosas de mortificação do corpo presentes na trajetória de certos eremitas, a contínua prática dos peditórios públicos pressupunha uma conduta de humildade próxima à penitência. Tanto é assim que, nas irmandades e ordens terceiras, as ocupações equivalentes de andadores e esmoleres não conferiam tanto status quanto os demais cargos administrativos. Ao abdicar da caridade pública para tornar-se um empreendedor e rentista, decididamente Manoel Correa se distancia da imagem, até certo ponto convencional, que se dispõe até agora para os ermitãos coloniais.

\section{Demandas ocorridas na execução do testamento do ermitão Manoel Correa}

Nos anos que se seguiram à morte de Manoel Correa, as autoridades episcopais e da Coroa disputaram sobre a correta interpretação das últimas vontades do ermitão. Como assinalado no início do texto, Manoel Correa tinha a intenção de transformar a ermida do Desterro em sede de um convento de frades carmelitas descalços. Esse desejo, expresso solenemente no testamento, se pode ser interpretado em termos de afinidade devocional, permite também aproximá-lo de um padrão encontrado em membros da elite senhorial, isto é: o patrocínio de fundações monásticas e conventuais. Assim, em 1687, José de Barcelos Machado, que havia ocupado a provedoria da Santa Casa da Misericórdia do Rio de Janeiro, e fora também o instituidor do morgado de Capivari na região dos Campos dos Goitacazes, fez a doação anual de 25 bois de seus currais para o Convento franciscano de Nossa Senhora dos Anjos da cidade de Cabo Frio, tornando-se por essa via padroeiro 
do Convento. A obrigação teria continuidade entre seus descendentes (SANTA MARIA, 2007, p. 60-61; RÖWER, 1957, p. 380-381; OLIVEIRA, 2014, p. 354). De modo análogo, em 1704, D. Inês de Andrade, viúva do fidalgo da Casa Real Francisco Teles Barreto, fez uma escritura de doação da Ilha da Caqueirada, situada na baía de Guanabara, aos religiosos franciscanos capuchos do Rio de Janeiro. O filho do citado casal, Antônio Teles de Menezes, que ocupava o cargo de juiz dos órfãos da cidade do Rio de Janeiro tornou-se, desde 1719, padroeiro particular do Convento do Bom Jesus que se fundou na referida ilha, concedendo-lhe a esmola anual de $60 \$ 000$ réis. Como parte das honras reservadas aos patronos conventuais, a sepultura dos Teles de Menezes foi instalada em local de destaque na nave da igreja conventual, ornada com o brasão da família. (ROWER, 1957, p. 440-446; FRAGOSO, 2011, p. 15).

À diferença dos dois indivíduos mencionados, Manoel Correa era reinol, não pertencia à nobreza da terra e nem possuía herdeiros. No momento em que faleceu, o Convento de carmelitas descalços era apenas um projeto. Assim, com relação às disposições para o sepultamento, determinou que o seu corpo fosse "amortalhado no hábito dos Religiosos Carmelitas descalços, de que se lhe dará de esmola dez mil réis, e será sepultado na ermida de Nossa Senhora do Desterro, do arco para frente da Capela-mor". A escolha de um local privilegiado para a sepultura assinala a busca de signos de prestígio social e de maior sacralidade por parte do ermitão. As cem missas de corpo presente e os dois ofícios que determinou celebrar no dia do falecimento, sendo um cantado pelos religiosos carmelitas e o outro com nove lições, igualmente aproximam Manoel Correa de um padrão identificável mais comumente em membros das elites coloniais (CAMPOS, 2013, p. 135-153). O total de gastos com hábito, acompanhamento de sacerdotes, ofícios e missas foi de $130 \$ 000$ réis.

Conforme será visto, o foco dos litígios em que se envolveram diferentes autoridades se encontrava em duas cláusulas do testamento que, analisadas antes de forma separada, são citadas na íntegra:

\begin{abstract}
Declaro que todos estes bens foram adquiridos por mim com muito trabalho, e com tenção de mandar fazer neste sítio um Convento de religiosos Carmelitas descalços para melhor se conservar e aumentar a devoção da dita Senhora do Desterro, e assim quero e ordeno que se faça neste sítio o dito Convento com a invocação de Nossa Senhora do Desterro, e a mesma Senhora do Desterro instituo por minha universal herdeira de todos os bens declarados, móveis de casa, prata e ouro, dinheiro e tudo o mais que se achar por meu falecimento, e me possa pertencer. (f. 100).
\end{abstract}

Como testamenteiros responsáveis pela execução das suas últimas vontades, o ermitão nomeou, em primeiro lugar, os padres carmelitas descalços e, em segundo lugar, o capitão Luís da Motta.

O protagonista principal da disputa relativa à interpretação e à execução do testamento foi, no campo episcopal, o vigário-geral do Rio de Janeiro e deão da Sé da mesma cidade, o cônego Gaspar Gonçalves de Araújo. Segundo um conhecido cronista do Rio de Janeiro, 
o referido eclesiástico havia nascido na Vila de Santos em 1661, formando-se depois na Faculdade de Leis da Universidade de Coimbra. Retornou depois ao lugar de nascimento, indo exercer os cargos de vigário da vara e de juiz de casamentos. Em 1706, principiou a prática da advocacia na cidade da Bahia, onde entre os sábios locais era reputado como "literato da melhor nota, assim nas matérias de Jurisprudência Civil, Canônica, Teológica, como nas do Foro, sobre todas era ouvido e consultado pelo arcebispo". Atendendo às súplicas do bispo D. Francisco de São Jerônimo, assumiu na diocese fluminense as varas de provisor e vigário-geral, obtendo também, em 1714, a dignidade decanal. Na referida diocese, atuou também como comissário do Santo Ofício. Após servir sucessivos bispos, faleceu em 1754 com mais de 93 anos, escolhendo como local de sepultura a capela da Ordem Terceira do Carmo (ARAÚJO, 1946, v. 6, p. 69-73). É interessante verificar como a trajetória do vigário geral Gaspar Gonçalves ganha impulso junto a dois prelados diocesanos - D. Sebastião Monteiro da Vide e D. Francisco de São Jerônimo - em cujos perfis também se destacavam a formação em leis, o exercício prévio de diversos cargos menores e as ligações políticas (PAIVA, 2011, p. 33-38). Conforme uma sugestiva análise, entre os anos de 1680 e 1720, os canonistas ganham preferência nos provimentos episcopais, vindo a constituir um dos perfis próprios dos bispos no Império português (PAIVA, 2006, p. 147154). No Rio de Janeiro, cuja diocese fora instituída em 1676, consistia matéria premente a defesa da jurisdição episcopal, tarefa que será desempenhada com rigor pelo vigário geral Gaspar Gonçalves. Conforme reconheceu monsenhor Pizarro, também ele cônego da Sé fluminense: "firme sempre nas determinações dos Sagrados Cânones e nas decisões das Leis Pátrias, nunca temeu que nas instâncias superiores fosse desatendido o seu juízo sobre as dependências tratadas perante ele, nem revogadas suas sentenças nos tribunais". (ARAÚJO, 1946, v. 6, p. 72).

No campo das autoridades régias, o pleito foi sustentado pelo procurador da Real Fazenda e Coroa, o doutor Salvador da Silva Brandão. Todo o litígio foi intermediado pelo juiz dos feitos da Coroa, o doutor Fernando Pereira de Vasconcellos. Tendo elaborado o testamento e obtido sua aprovação junto ao tabelião Vicente de Andrade, em julho de 1716, em outubro desse ano o ermitão já havia falecido. Nessa mesma ocasião, o vigário geral Gaspar Gonçalves fez o inventário dos bens de Nossa Senhora do Desterro que existiam na cidade. Encerrando-se o inventário, o cônego tesoureiro-mor Gaspar Ribeiro Pereira foi nomeado por provisão do bispo D. Francisco de São Jerônimo como administrador dos bens de Nossa Senhora do Desterro, "para dar conta deles e dos seus rendimentos" (f. 128). Segundo monsenhor Pizarro, o tesoureiro-mor manteve-se na administração dos referidos bens até 1732. (ARAÚJO, 1946, v. 6, p. 88).

As providências tomadas pelo bispo e pelo vigário geral em exercício foram questionadas pelo procurador da Real Fazenda e Coroa. No agravo que impetrou no Rio de Janeiro junto ao Juízo dos Feitos da Coroa, com data de 13 de novembro de 1716, Salvador da Silva Brandão acusava as autoridades diocesanas de "opressão e notória violência" cometidas contra a vontade do ermitão. A posse dos bens sob a custódia dos testamenteiros que Manoel Correa nomeara fora violada pelas autoridades episcopais, "inventariando-os 
e dando-lhes novo administrador, usando neste particular de sua eclesiástica jurisdição, [...] com notória e manifesta usurpação da jurisdição de Vossa Majestade". (f. 76).

Para justificar tais afirmativas, o procurador da Real Fazenda e Coroa se sustentou em três argumentos: o estatuto jurídico leigo do ermitão; a lei da alternativa com relação ao cumprimento dos testamentos; e as solenes declarações contidas nas últimas vontades. Com relação ao primeiro ponto, Salvador da Silva Brandão afirmou: "é sem a menor dúvida que o dito testador, ainda que eremitão [sic], era Leigo de profissão, isento conforme a disposição do Concílio Tridentino da jurisdição Eclesiástica, e somente sujeito à Real, como qualquer Donato Ex. Ord. Lib. 2ำ, título $2^{\circ}$ ". Brandão concluiu o primeiro ponto lembrando que a matéria era "tão sem controvérsia, que afirmar o contrário seria absurdo e temeridade nunca vista" (f. 76). A fonte de direito citada pelo procurador da Real Fazenda e Coroa, que tratava de "como os Donatos de S. João, e os da Terceira Ordem de São Francisco, e os Irmãos de algumas Ordens responderão perante as Justiças del Rei", dizia expressamente que:

Porquanto alguns Priores e Comendadores da Ordem do Hospital de S. João de Jerusalém lançam muitos hábitos da dita Ordem a homens, assim casados como solteiros, a que eles chamam Donatos, para terem os privilégios dela, e se isentarem de nossa jurisdição, os quais per Direito não são verdadeiros Religiosos, nem devem gozar de privilégios deles: mandamos que não se guarde privilégio algum, que por razão dos ditos hábitos aleguem ter, a nenhum dos sobreditos. (ALMEIDA, 1870, p. 422)

Quanto à discussão da lei da alternativa, segundo a qual a fiscalização sobre a execução dos testamentos cabia alternativamente às justiças eclesiástica e secular, conforme a sucessão dos meses no ano (MARTINS, 2015, p. 51-73), o defensor das prerrogativas da Coroa concluiu que falecendo em outubro "o dito testador em o mês da alternativa do secular, a este toca fazer dar à execução o dito testamento e cumprimento às suas pendências, das quais uma e principal é fazer inventário dos bens que testou" (f. 78). Por fim, no que tange ao último ponto, Salvador da Silva Brandão alegava que era insuficiente, como foi feito pelas autoridades do bispado, "presumir que os bens deixados pelo testador são da mesma Igreja de Nossa Senhora do Desterro, por suas esmolas adquiridos, e que deles o Eremitão não podia testar por não serem seus". Não era possivel ter certeza disso, pois Manoel Correa o negava expressamente no testamento. Conforme foi discutido antes, o ermitão declarara que os bens tinham sido adquiridos com "muito trabalho" pessoal.

A resposta ao agravo, da autoria de Gaspar Gonçalves de Araújo, foi elaborada apenas um dia depois da ação do procurador da Fazenda Real e Coroa. Segundo o deão e vigário geral do Rio de Janeiro, a matéria do recurso era "sofística e sonhada". Na defesa, o argumento central brandido pela autoridade eclesiástica era de que os bens em litígio "por seus justos e autênticos títulos, documentos e memórias, ou assentos do mesmo ermitão, voz e fama constante do povo, eram já em vida e sempre foram pertencentes à Nossa Senhora do Desterro e à sua ermida" (f. 86). Em decorrência disso, o ermitão Manoel Correa "não era mais que um procurador e tesoureiro dos bens pertencentes a Nossa Senhora do Desterro, e não tinha nem possuía coisa alguma própria" (f. 85). Gaspar Gonçalves de 
Araújo argumentou que o testador faltara com a verdade quando disse que os bens eram próprios e adquiridos "com muito trabalho", pois "não declarou qual fora o trabalho, o título ou modo de aquisição do dinheiro e bens com que comprara e adquirira as fazendas ou propriedades de que faz menção, nem de quem eram ou como houvera os escravos" (f. 86). Acusou também de dissimulação quem fizera ou ditara o testamento:

Porque primeiramente se quis nele ocultar que 0 testador era Ermitão de Nossa Senhora do Desterro, e por tal se não nomeou, como se estivera em terra de cego, que o não vissem no discurso [sic] da sua vida vestido de um saial e hábito penitente, com barba longa, vivendo das esmolas que sempre tirou para a mesma senhora, a cuja ermida foi agregado, de que todo o povo desta Cidade e recôncavo é testemunha de vista. (f. 86).

Como é evidente, o vigário geral trouxe para a sua defesa a representação mais convencional da figura do ermitão, alegando que pedira esmolas ao longo de toda a sua vida, embora, como já foi analisado, não tenha sido encontrada uma prova cabal para esse fato, e também tenha ficado evidente de que os recursos das esmolas foram aos poucos complementados com outras fontes de renda. Para a autoridade eclesiástica, não havia provas de que os bens eram do ermitão: antes, as escrituras e outros documentos reunidos deixavam patente que os bens pertenciam à Senhora do Desterro. O vigário geral terminou a primeira parte da defesa usando de ironia:

E seria coisa assaz galante entrar um Leigo com uma mão atrás outra adiante a vestir-se de saco, e adir-se com Licença do Prelado a uma Igreja, ou Ermida, e sem ter outro patrimônio nem exercício mais que tirar esmolas com a caixinha de Nossa Senhora, ou do Santo titular da dita Igreja, e ir aumentando os bens dela com as mesmas esmolas, sendo em sua vida um simples procurador e tesoureiro dos ditos bens, e testar deles, o que não podem fazer os mesmos Prelados, a cujo governo, administração e jurisdição sujeita a dita Igreja! (f. 91)

Além do argumento central da defesa, Gaspar Gonçalves de Araújo tentou invalidar outro ponto importante do agravo do procurador da Real Fazenda e Coroa, isto é, de que sendo leigo, o ermitão estava sujeito somente à justiça secular. "Pelo contrário", argumentou o vigário geral, "se mostra que era da jurisdição e foro eclesiástico, porque a vida dos Ermitães é aprovada tanquam in statu penitentium; e o de que se trata propriamente fazia vida eremítica, agregado à Ermida de Nossa Senhora do Desterro no subúrbio da Cidade, onde vivia à obediência do Prelado ordinário" (f. 87). Além disso, o trecho das Ordenações Filipinas citado pelo Procurador da Real Fazenda e Coroa não tratava dos ermitãos. Para concluir a sua argumentação, Gaspar Gonçalves de Araújo apresentou uma resolução de 1594 da Sagrada Congregação dos Bispos, que considerava os ermitãos como pessoas eclesiásticas: "Eremitae, qui a statu secular ad eremum assumpto habitu, loco et modo vivendi de Licentia Episcopi transeunt, dicuntur personae ecclesiastica" (f. 88). Na resposta do vigário geral do Rio de Janeiro, qualquer ermitão que vivia com hábito, agregado a alguma capela situada no "ermo" e com licença do bispo fazia necessariamente vida eremítica. 
As Constituições Primeiras do Arcebispado da Bahia, promulgadas pelo arcebispo D. Sebastião Monteiro da Vide no sínodo diocesano de 1707, e publicadas primeiramente em 1719 e 1720, não estipularam, de modo cabal, se os ermitãos estavam submetidos ao foro eclesiástico. Não obstante, há pelo menos um indício nesse sentido, pois o título que trata dos ermitãos encontra-se inserido no livro segundo, que cuidava das obrigações dos clérigos, párocos, freiras, entre outros agentes eclesiásticos. Segundo a legislação da Bahia, que devia ser aplicada a todas as dioceses do Estado do Brasil:

626. Nas ermidas de nosso arcebispado, e principalmente naquelas onde há romagem e devoção, é necessário haver ermitães para o culto divino e limpeza delas. E para que se não introduzam aqueles que não será bem se admitam, mandamos que, pertencendo a apresentação a outrem, apresentem para ermitães homens diligentes, de idade conveniente e de boa vida e costumes, e não poderão apresentar mulheres.

627. E não pertencendo a apresentação a outrem, Nós ou nosso provisor proveremos as ditas ermidas de ermitães que tenham as mesmas partes e qualidades, e nem uns nem outros poderão servir sem carta de ermitania passada por Nós [...].

629. Não usarão de hábitos de religiosos ou clérigos, mas poderão trazer roupetas pardas compridas ou de outra cor honesta, ou outros vestidos decentes. Não viverão nas ditas ermidas mas em casas separadas. Não consentirão que nas ditas ermidas algumas pessoas durmam, comam, joguem, bailem ou façam coisa semelhante, posto que seja com pretexto de romagem, o que tudo cumprirão, sob pena de serem castigados arbitrariamente conforme sua culpa. (VIDE, 2010, p. 372). ${ }^{12}$

A réplica do procurador da Real Fazenda foi apresentada ao Juízo dos Feitos da Coroa em janeiro de 1717. Citando os comentários de Agostinho Barbosa às Ordenações Filipinas, Salvador da Silva Brandão rechaçou a interpretação dada pelo vigário geral, argumentando que

Se a Ord. Lib. 2, título 2 expressamente não fala em os Ermitães, contudo também deles se deve entender, e principalmente no nosso Ermitão (como dos mais que há em todo o Estado do Brasil), o qual sempre viveu sem certo modo, regra ou instituto de vida aprovado pela Igreja, nem teve tonsura, e muito menos professou religião alguma, e por isso assim ele, como os demais desta qualidade, é sujeito à jurisdição Real e isento da Eclesiástica, de cujo foro não goza. (f. 94).

Em sua réplica, o procurador da Coroa e Fazenda continuou a identificar elementos que, presentes no modo de vida dos ermitãos na Colônia, os afastavam do pertencimento ao estado e ao foro eclesiásticos:

Muitos e muitos deles são casados e carregados de filhos, vivendo como qualquer secular, hoje com uma caixinha tirando esmola por uma ermida, e amanhã trabalhando por seus ofícios já sem caixinha, e sem barba nem saial! Boa casta por certo de eclesiásticos e de ermitães para gozarem do privilégio de foro! Monstruosidade enfim. (f. 95). 
Apesar da expressa proibição das Constituições Primeiras do Arcebispado da Bahia, de fato há situações documentadas de ermitãos com prole reconhecida. Um dos exemplos mais famosos foi o ermitão de Nossa Senhora da Glória da cidade do Rio de Janeiro, Antônio Caminha. Em 1671, fundou a ermida onde cultuava a Virgem, cujas terras lhe foram doadas mais tarde, em 1699, pelo doutor Cláudio Gurgel do Amaral. Antônio Caminha era vinculado à Ordem Terceira de São Francisco, e foi pai do sacerdote João Caminha e de Antônia, a quem beneficiou com herança (FAZENDA, 1919, p. 299-303; SANTA MARIA, 2007, p. 21-24; TELLES, 1969, p. 57-63). No caso de Manoel Correa, não foi possível identificar a existência de prole. Nas casas em que habitava o ermitão de Nossa Senhora do Desterro, vivia com ele o seu sobrinho, o padre Francisco Correa, que atuou como capelão da ermida do Desterro e como procurador de seu tio. (f. 57).

A réplica do procurador da Coroa e Fazenda voltou a colocar em cena a questão da fonte dos recursos geridos pelo ermitão, isto é, se tinham origem nas esmolas dos fiéis ou na sua diligência pessoal. Quanto a esse tema, descontando o tom hiperbólico, a resposta do procurador se aproxima da análise que foi feita no item anterior do texto.

\begin{abstract}
Se mostra dos documentos juntos pelo Reverendo Agravado ser impossivel que tanto Cabedal quanto consta do inventário fosse adquirido por esmolas, como se todos os fiéis só a invocação da Senhora do Desterro tivessem devoção, e só para esta concorressem com suas esmolas; quando é certo que havendo nesta Capitania e Bispado tantas ermidas, todas são pobríssimas e nenhuma tem as esmolas que o Reverendo Agravado quer que tenha a dita Senhora do Desterro, do que se infere ser verdadeira a confissão do Ermitão no seu solene testamento. (f. 95).
\end{abstract}

Coerentemente com a defesa traçada, o procurador da Real Fazenda e Coroa procurou construir uma representação do ermitão oposta à imagem convencional de asceta, penitente, habitante do "ermo" e sujeito diretamente à autoridade da Igreja, que tinha sido apresentada pelo vigário geral. Para Salvador da Silva Brandão, o ermitão Manoel Correa, como era leigo, sem tonsura, sem regra ou estatutos aprovados pela Santa Sé, devia estar inteiramente sujeito à jurisdição secular. Além disso, destacou também o esforço pessoal do ermitão em constituir o patrimônio de Nossa Senhora do Desterro: "sem dúvida testificaria o povo que muitas e muitas vezes viram ao dito Ermitão descalço com os pés no chão; e nu da cinta para cima trabalhando em obras de casas e tirando por um carro de pedra só a fim de juntar o cabedal que juntou". Segundo o procurador régio, nas escrituras dos imóveis comprados para Nossa Senhora do Desterro, não havia provas de que "fossem compradas com o dinheiro das esmolas, as quais como tão tênues não era possivel chegarem para isso". (f. 95-96).

Por fim, o procurador da Fazenda Real e Coroa, lembrando os direitos do monarca como padroeiro da Ordem de Cristo no ultramar, argumentou que a ermida de Nossa Senhora do Desterro pertencia à jurisdição do referido padroado. Assim, considerava inválida a provisão de ereção da referida ermida passada em princípios do século XVII pela autoridade eclesiástica do Rio de Janeiro. Em consonância com aquela subordinação, os 
bens que pertenciam ao patrimônio de Nossa Senhora, uma vez adquiridos "sem especial licença de Vossa Majestade são perdidos para a sua Real Coroa". (f. 98).

A sentença do juiz dos Feitos da Coroa foi promulgada em abril de 1717. O magistrado concordou com todas as alegações apresentadas pelo procurador da Real Fazenda e Coroa, mandando notificar o vigário geral para que desistisse "da força e violência que faz aos seus vassalos, e jurisdição real, mandando entregar a seus juízes os bens do dito Ermitão, e os da capela do defunto Manoel Correa". Em conformidade com a sentença referida, expediu-se em junho de 1717 a primeira carta rogatória em nome do rei contra a suposta intromissão do vigário geral na gestão dos bens do ermitão de Nossa Senhora do Desterro. Outra carta foi expedida mais tarde, em outubro de 1717. Nas duas justificativas que apresentou para não cumprir o que se ordenava nas cartas, Gaspar Gonçalves de Araújo insistiu que os bens não eram próprios do ermitão "como errada e apaixonadamente quer o Procurador da Coroa, mas [...] que são, eram e foram, ainda antes de morrer o dito Ermitão, da mesma Senhora" (f. 106). Segundo o vigário geral, a referida percepção foi partilhada até mesmo pelos testamenteiros nomeados pelo ermitão, o capitão Luís da Motta Leite e Fr. Custódio de Jesus Maria, frade carmelita descalço, que desistiram de aceitar o encargo para o qual tinham sido nomeados, pois sabiam "que todas aquelas propriedades eram de Nossa Senhora do Desterro" (f. 111). Gaspar Gonçalves de Araújo concluiu a justificativa manifestando as suas esperanças de que, na Mesa do Desembargo do Paço, "se julgue não serem bem passadas as cartas" rogatórias (f. 116). Mas não foi possivel acompanhar o desenvolvimento do pleito junto ao mais elevado tribunal régio.

\section{Considerações finais}

Nos anos posteriores, é possível reconstituir algumas informações sobre o destino da capela de Nossa Senhora do Desterro e dos bens anexos. Mesmo que não tenham sido encontradas informações referentes à decisão da demanda junto à Mesa do Desembargo do Paço, parece fidedigna a informação de monsenhor Pizarro, segundo a qual a referida ermida permaneceu sob a administração diocesana até 1732. Assim, não tiveram efeito imediato as disposições do ermitão tocantes ao destino dos numerosos bens. Entre 1729 e 1730, o bispo diocesano D. Antônio de Guadalupe autorizou a permanência na capela do Desterro de dois missionários barbadinhos italianos, isto é, da Ordem dos Frades Menores capuchinhos (PALAZOLLO, 1966, p. 63-67). Em 1732, houve novas alterações. O ouvidor do Rio de Janeiro, Fernando Leite Lobo, recebeu ordens régias para tomar posse da ermida do Desterro, a cuja decisão se opôs com embargos o procurador da mitra diocesana. Além de tomar posse da administração e dos bens da capela do Desterro, o ouvidor geral deixou no local "um Religioso franciscano italiano para tratar do asseio da dita ermida", tarefa que era antes desempenhada por Manoel Correa (f. 34). Segundo o livro de receita e despesa da capela, cujas contas de 1730-1731 já tinham sido tomadas pelo bispo, a receita no período foi de 4:847\$400 réis, e a despesa de 4:246\$150 réis, gerando um rendimento líquido anual de $601 \$ 250$ réis. (f. 34-35). 
Em 1735, possivelmente pelo interesse despertado no campo religioso da cidade pelos avultados bens que acumulara, a administração da capela de Nossa Senhora do Desterro passou por novas mudanças. Pelo decreto de 7 de junho do referido ano, enviado pelo Conselho Ultramarino, o monarca D. João V autorizou os religiosos franciscanos do Convento de Santo Antônio do Rio de Janeiro, duros rivais dos capuchinhos, a "construir um Seminário eclesiástico com os rendimentos da Capela chamada de Nossa Senhora do Desterro, bem como de seus bens, com a declaração de que se o referido seminário não for edificado", revogar-se-ia a mercê e "os rendimentos da capela voltarão para a Coroa" (f. 1). Segundo informa o padre Arlindo Rubert, desde 1734 o bispo diocesano D. Fr. Antônio do Guadalupe vinha pleiteando o "parco patrimônio" da ermida do Desterro. Sustentado com os referidos bens, o Seminário de São José foi de fato fundado em 1739, e o bispo o confiou "à direção do clero secular". Finalmente, em 1766, D. Fr. Antônio do Desterro devolveu "o patrimônio inicial para a fundação do mosteiro de Santa Teresa", cujo edifício foi levantado no mesmo local onde existia a ermida do Desterro (RUBERT, s/d, v. 2, p. 276). A partir de um caminho muito tortuoso, as últimas vontades do ermitão acabaram sendo cumpridas em parte, com a abertura definitiva do Convento de Santa Teresa do Rio de Janeiro das religiosas carmelitas descalças, no episcopado de D. José Joaquim Castelo Branco, patrocinado com as rendas da antiga capela de Nossa Senhora do Desterro. (ALGRANTI, 1993, p. 95-96; MARTINS, 2012, p. 70-81).

Além de dar testemunho sobre uma das formas de vida religiosa menos conhecidas da sociedade colonial, e de descortinar certas variedades que aquela assumiu no contexto enfocado, a trajetória do ermitão Manoel Correa permite, de modo ímpar, lidar com uma série de processos então em curso na cidade do Rio de Janeiro: a urbanização mais acelerada, em que aparecia com destaque a acumulação de imóveis urbanos por parte das instituições eclesiásticas; os vínculos estabelecidos entre os fiéis e os entes sagrados por meio das promessas; as redes de proteção e de aliança forjadas por ordens religiosas, autoridades seculares e fiéis leigos; e, por fim, os conflitos de jurisdição entre as justiças secular e eclesiástica.

\section{Referências}

ALDEN, Dauril. The Making of an Enterprise: The Society of Jesus in Portugal, Its Empire, and Beyond (1540-1750). Stanford: Stanford University Press, 1996.

ALMEIDA, Cândido Mendes de (Ed.). Ordenações Filipinas. Rio de Janeiro: Instituto Philomatico, 1870. (Ed. fac-símile da Fundação Calouste Gulbenkian.)

ALGRANTI, Leila Mezan. Honradas e devotas: mulheres da Colônia. Condição feminina nos conventos e recolhimentos do sudeste do Brasil, 1750-1822. Rio de Janeiro: José Olympio; Brasília: Ed. UnB, 1993. 
ARAÚJO, José de Souza Azevedo Pizarro e, monsenhor. Memórias históricas do Rio de Janeiro. v. 2 e 3. Rio de Janeiro: Imprensa Nacional, 1945-1946.

BETHENCOURT, Francisco. O imaginário da magia: feiticeiras, adivinhos e curandeiros em Portugal no século XVI. São Paulo: Companhia das Letras, 2004.

BICALHO, Fernanda. A cidade e o império: o Rio de Janeiro no século XVIII. Rio de Janeiro: Civilização Brasileira, 2003.

BLUTEAU, Raphael. Vocabulario portuguez e latino (...). Coimbra: no Colégio das Artes da Companhia de JESU, Ano 1713. v. 3.

BORGES, Célia Maia. Os eremitas e o ideal de santidade no imaginário português: o deserto dos carmelitas descalços no séc. XVII. Lusitânia sacra, Lisboa, n. 23, p. 189-206, jan.-jun. 2011.

BORGES, Célia Maia. Os leigos e a administração do sagrado: o irmão Lourenço de N. Sra. e a Irmandade de Nossa Senhora Mãe dos Homens - Minas Gerais, século XVIII. Locus: Revista de História, Juiz de Fora, v. 21, n. 2, p. 397-414, 2015.

BOXER, C. R. Salvador de Sá e a luta pelo Brasil e Angola, 1602-1686. São Paulo: Nacional, Edusp, 1973.

BOURDIEU, Pierre. Gênese e estrutura do campo religioso. In: BOURDIEU, Pierre. A economia das trocas simbólicas. 2.ed. São Paulo: Perspectiva, 1987. p. 27-78.

CALDERÓN, Valentin. Biografia de um monumento: o antigo Convento de Santa Teresa da Bahia. Salvador: Ed. Beneditina, 1971. (Coleção Estudos Baianos, UFBA, n. 3)

CAMPOS, Adalgisa Arantes. As irmandades de São Miguel e as Almas do Purgatório: culto e iconografia no Setecentos mineiro. Belo Horizonte: C/Arte, 2013.

CARVALHO, José Adriano de Freitas. O eremitismo em Portugal na Época Moderna: homens e imagens. Via Spiritus, Porto, n. 9, p. 83-145, 2002.

CASTANHO, Gabriel C. G. A polissemia (social) do deserto: uma história do topos histórico e historiográfico da solidão monástica no contexto latino medieval. Revista de História, São Paulo, n. 173, p. 115-139, jul.-dez. 2015.

CHAHON, Sergio. Os convidados para a ceia do Senhor: as missas e a vivência leiga do catolicismo na cidade do Rio de Janeiro e arredores (1750-1820). São Paulo: Edusp, 2008.

COSTA, F. A. Pereira da. A Ordem carmelitana em Pernambuco. Recife: Arquivo Público Estadual, 1976. 
CUNHA, D. Rodrigo da, arcebispo. Constituições synodaes do Arcebispado de Lisboa. Novamente feitas no Synodo diocesano, que celebrou na Sé Metropolitana de Lisboa [...], em os 30 dias de Mayo de 1640 [...]. Acabadas de imprimir e publicadas por mandado dos muito Reverendos Senhores Deão e Cabido da santa Sé de Lisboa, Sede vacante, no ano de 1656. Em Lisboa: Com todas as licenças necessárias. Na Officina de Paulo Craesbeeck, 1656.

FAZENDA, José Vieira. Os provedores da Santa Casa da Misericórdia do Rio de Janeiro. Rio de Janeiro: Oficinas Gráficas da Fundação Romão de Mattos Duarte, 1960.

FAZENDA, José Vieira. Antiqualhas e memórias do Rio de Janeiro. Revista do IHGB, Rio de Janeiro, t. 86, v. 140, 1919.

FRAGOSO, João. Prefácio. In: GUEDES, Roberto (Org.). Dinâmica imperial no Antigo Regime português: escravidão, governos, fronteiras, poderes, legados (séculos XVII-XIX). Rio de Janeiro: Mauad X, 2011. p. 13-17.

FRAGOSO, João; FLORENTINO, Manolo. O arcaísmo como projeto: mercado atlântico, sociedade agrária e elite mercantil no Rio de Janeiro, c.1790-c.1840. 2.ed. Rio de Janeiro: Sette Letras, 1996.

FRAGOSO, João. A nobreza da República: notas sobre a formação da primeira elite senhorial do Rio de Janeiro (séculos XVI e XVII). Topoi: Revista de História, Rio de Janeiro, n. 1, p. $45-122,2000$.

FRAGOSO, João. Fidalgos e parentes de pretos: notas sobre a nobreza principal da terra do Rio de Janeiro (1600-1750). In: FRAGOSO, João; ALMEIDA, Carla Maria Carvalho de; SAMPAIO, Antônio Carlos Jucá de. Conquistadores e negociantes: histórias de elites no Antigo Regime nos trópicos. América lusa, séculos XVI a XVIII. Rio de Janeiro: Civilização Brasileira, 2007. p. 33-120.

FRIDMAN, Fania. Donos do Rio em nome do rei: uma história fundiária da cidade do Rio de Janeiro. Jorge Zahar: Garamond, 1999.

LACARRIĖRE, Jacques. Os Padres do Deserto: homens embriagados de Deus. 2.ed. São Paulo: Loyola, 2002.

MATA, Sérgio da. Para uma história das formas de ascetismo leigo em Minas colonial: ocaso dos ermitães. In: ASSIS, Angelo Adriano Faria de; PEREIRA, Mabel Salgado (Orgs.). Religiões e religiosidades: entre a tradição e a modernidade. São Paulo: Paulinas, 2010. p. 29-44.

MARTINS, William de Souza. Membros do corpo místico: ordens terceiras no Rio de Janeiro (c.1700-1822). São Paulo: Edusp, 2009. 
MARTINS, William de Souza. Práticas do corpo e conhecimentos do além da beata fluminense Jacinta de São José (c.1744-1754). In: ANDRADE, Marta Mega de; SEDREZ, Lise Fernanda; MARTINS, William de Souza (Orgs.). Corpo: sujeito e objeto. Rio de Janeiro: Ponteio, 2012. p. 155-180.

MARTINS, William de Souza. Os irmãos terceiros franciscanos e carmelitas e a Justiça Eclesiástica do Rio de Janeiro. Locus, Juiz de Fora, v. 21, p. 287-317, 2015.

MELVIN, Karen. Building Colonial Cities of God: Mendicant Orders and Urban Culture in New Spain. Stanford: Stanford University Press, 2012.

OLIVEIRA, Anderson José Machado de. Os processos de habilitação sacerdotal dos homens de cor: perspectivas metodológicas para uma História Social do catolicismo na América portuguesa. In: FRAGOSO, João; GUEDES, Roberto; SAMPAIO, Antônio Carlos Jucá de. Arquivos paroquiais e História Social na América lusa: métodos e técnicas de pesquisa na reinvenção de um corpus documental (séculos XVII e XVIII). Rio de janeiro: Mauad X, 2014. p. 329-362.

PAIVA, José Pedro. D. Sebastião Monteiro da Vide e o episcopado brasileiro em tempo de renovação (1701-1750). In: FEITLER, Bruno; SOUZA, Evergton Sales (Orgs.). A Igreja no Brasil: normas e práticas durante a vigência das Constituições Primeiras do Arcebispado da Bahia. São Paulo: Editora Unifesp, 2011. p. 29-59.

PAIVA, José Pedro. Os bispos de Portugal e do Império, 1495-1777. Coimbra: Imprensa da Universidade de Coimbra, 2006.

PALAZZOLO, Fr. Jacinto de, OFM Cap. Crônica dos capuchinhos do Rio de Janeiro. Petrópolis: Vozes, 1966.

ROWER, Fr. Basílio, OFM. Páginas de História franciscana no Brasil. Esboço histórico e documentado de todos os conventos e hospícios fundados pelos religiosos franciscanos da Província da Imaculada Conceição do Sul do Brasil, desde 1591 a 1758, e das Aldeias de índios administrados pelos mesmos religiosos desde 1692 a 1803. 2.ed. rev. Petrópolis: Vozes, 1957.

RUBERT, Arlindo, Pe. A Igreja no Brasil: expansão missionária e hierárquica (século XVII). v. 2. Santa Maria: Palocci, s/d.

RUBIAL GARCÍA, Antonio. Profetisas y solitários: espacios y mensajes de uma religión dirigida por ermitaños y beatas laicos em las ciudades de Nueva España. México: UNAM: Fondo de Cultura Económica, 2006.

SAMPAIO, Antônio Carlos Jucá de. Na encruzilhada do império: hierarquias sociais e conjunturas no Rio de Janeiro (c.1650-c.1750). Rio de Janeiro: Arquivo Nacional, 2003. 
SAMPAIO, Antônio Carlos Jucá de. Fluxos e refluxos mercantis: centros, periferias e diversidade regional. In: FRAGOSO, João; GOUVÊA, Maria de Fátima (Orgs.). O Brasil colonial, 1580-1720. v. 2. Rio de Janeiro: Civilização Brasileira, 2014. p. 379-418.

SANTA MARIA, Fr. Agostinho de. Santuario mariano, e historia das imagens milagrosas de nossa senhora (...) tomo decimo e ultimo. Reedição ilustrada da edição de 1723. Rio de Janeiro: Inepac, 2007.

SCHWARTZ, Stuart B. Segredos internos: engenhos e escravos na sociedade colonial (1550-1835). São Paulo: Companhia das Letras, 1995.

SCHWARTZ, Stuart B. Alforria na Bahia, 1684-1745. In: SCHWARTZ, Stuart B. Escravos, roceiros e rebeldes. Bauru: EDUSC, 2001. p. 171-218.

SMET, Joaquín, O. Carm. Los carmelitas. Historia de la Orden del Carmen: I - Los Orígenes. En busca de la identidad. Madrid: Biblioteca de Autores Cristianos, 1987.

SOUZA, Jorge Victor de Araújo. Para além do claustro: uma história social da inserção beneditina na América portuguesa, c.1580-c.1690. Niterói: Ed. da UFF, 2014.

TELLES, Augusto C. da Silva. Nossa Senhora da Glória do Outeiro. Rio de Janeiro: Agir, 1969.

VASCONCELLOS, Pe. Simam de, SJ. Vida do p. Joam d'Almeida da Companhia de IESU na Provincia do Brazil (...). Em Lisboa, com todas as licenças necessárias. Na Officina Craesbeeckiana. Ano 1658.

VELASCO BAYÓN, Balbino, O. Carm. História da Ordem do Carmo em Portugal. Lisboa: Paulinas, 2001.

VIDE, D. Sebastião Monteiro da, arcebispo. Constituições Primeiras do Arcebispado da Bahia. Estudo introdutório e edição: Bruno Feitler e Evergton Sales Souza. São Paulo: Edusp, 2010. 


\section{Notas}

1 AHU_ACL_CU_017, cx. 28, d. 2931. 1735, junho 7, Lisboa. Decreto do rei D. João V concedendo licença ao procurador [dos religiosos capuchos da Província da Imaculada Conceição de Nossa Senhora do Rio de Janeiro] para construir um seminário eclesiástico com os rendimentos da capela chamada Nossa Senhora do Desterro, bem como de seus bens (...), f. 100. Disponivel em: <http://resgate.bn.br/docreader/DocReader.aspx?bib=017_ RJ_AV>. Acesso em: maio 2016. Doravante, limitar-se-á a indicar no corpo do texto principal as folhas deste documento, correspondentes às imagens digitalizadas pelo Projeto Resgate. A ortografia das fontes foi atualizada, mantendo-se somente a grafia das maiúsculas no original. Os títulos das obras antigas foram mantidos no original. 2 Para a América Portuguesa, não há um estudo sistemático das atividades praticadas por segmentos diversos da sociedade colonial com a finalidade de favorecer a fundação de conventos ou hospícios das ordens mendicantes. Para o México colonial, ver o trabalho de MELVIN, 2012. Com relação às demais ordens regulares, como os jesuítas e beneditinos, existem estudos mais satisfatórios, que mostram a importância da relação entre aqueles institutos e os benfeitores seculares, quanto à formação do patrimônio sagrado. Para a Companhia de Jesus, ver ALDEN, 1996, p. 345-375; para a Ordem de São Bento, ver SOUZA, 2014, p. 63-102.

3 Para a análise do conceito de "campo religioso" e sua aplicação ao contexto do Antigo Regime, ver, respectivamente: BOURDIEU, 1987, p. 27-98; BETHENCOURT, 2004, p. 232-257. Por meio da utilização do referido conceito, pretende-se chamar a atenção para as tensões e conflitos a opor fiéis leigos e diferentes especialistas do sagrado, sem, entretanto, negar a existência de múltiplas alianças estabelecidas entre as duas partes.

4 Segundo o Diccionario de la lengua española, editado pela Real Academia Española (disponível em: <dle.rae. es>, acesso em: ago. 2016), o vocábulo "santero" designa, entre outros significados, a "persona que cuida de um santuario" e a "persona qui pide limosna, llevando de casa en casa la imagen de un santo", sentidos que se apontam, em língua portuguesa, para as atividades do ermitão. Segundo a mesma fonte, "ermitãno" designa a "persona que vive en soledad" como também "la persona que vive en uma ermitã y cuida de ella", sentidos que apontam, respectivamente, para o eremita e para o ermitão, sinal de que a língua espanhola está marcada também pela ambiguidade do termo.

5 Segundo um autor, o referido processo de enquadramento principiou-se na Idade Média: "a partir do controle deste lugar de solidão, a Igreja irá exercer seu papel mediador entre o mundo terrestre e o mundo espiritual, organizando (ou tentando organizar) as relações entre os homens. A solidão participa, assim, do funcionamento do sistema eclesial que se pretende ao mesmo tempo presente no mundo e fora dele" (CASTANHO, 2015, p. 137). 6 A referida discrepância pode ser talvez explicada por um erro de transcrição cometido por escrivães, já que o traslado da provisão do registro de fundação da capela de Nossa Senhora do Desterro do Rio de Janeiro que se encontra anexado à documentação do ermitão Manoel Correa não se baseou no documento original, que já se encontrava extraviado em princípios do século XVIII, e sim em uma "certidão autêntica em que se acha o traslado da dita provisão posto em uma petição feita ao llustríssimo Senhor D. Francisco de São Jerônimo, bispo que foi deste bispado" (f. 44-45).

7 Como padrão para situar os valores fornecidos no texto, Schwartz informa que a soldada de um feitor-mor de um engenho de açúcar era de $80 \$ 000$ réis em 1688 e de $60 \$ 000$ réis em 1711. Já o mestre de açúcar, o ofício melhor remunerado do engenho, podia receber de soldada $100 \$ 000$ réis nos dois periodos. Entre 1684 e 1709 , o preço médio de um escravo do sexo masculino, de idade entre 14 e 45 anos, oscilou entre 80 e $120 \$ 000$ réis. Todos os dados se referem à Bahia (Ver SCHWARTZ, 1995 e 2001, respectivamente).

8 A respeito do governo de Thomé Correa de Alvarenga ver: BOXER, 1973, p. 325-328. Além da rápida e acidentada passagem pelo governo da capitania do Rio de Janeiro, Thomé Correa foi provedor da fazenda e ocupou por três vezes a provedoria da Santa Casa da Misericórdia da referida cidade, entre 1651-1660 e 1671-1674. Faleceu em 1675, sepultando-se no adro da Misericórdia, coberto com os hábitos de São Francisco e da Ordem de Cristo (FAZENDA, 1960, p. 29-39). A respeito de outras práticas devocionais do referido governador ver: $\mathrm{CHAHON}$, 2008, p. 44.

9 A respeito da trajetória do vigário da freguesia de Irajá, ver OLIVEIRA, 2014, p.353-362.

10 Ver: <http://mauricioabreu.com.br/escrituras/>.

11 Sobre o rentismo, ver: FRAGOSO; FLORENTINO, 1996. Sobre a nobreza da terra, ver os trabalhos de FRAGOSO e BICALHO citados na bibliografia.

12 A maior parte do texto das Constituições baianas segue a legislação que anteriormente era aplicada a todos os bispados da América portuguesa. Ver: CUNHA, 1640, p. 307-308. 


\section{Agradecimentos}

Quero agradecer a Anderson José Machado de Oliveira, Beatriz Catão Cruz Santos, Célia Maia Borges, Evergton Sales Souza, Gabriel C. G. Castanho, Jacqueline Hermann e Mauro Dilmann pelos comentários e sugestões feitos às primeiras versões deste texto, apresentadas no VI Encontro Internacional de História Colonial (Bahia) e na reunião mensal do Laboratório Sacralidades da UFRJ.

William de Souza MARTINS. Professor Doutor. Instituto de História e Programa de PósGraduação em História Social, Universidade Federal do Rio de Janeiro. Lgo. de São Francisco de Paula, n. 1, Centro, 20051-070 Rio de Janeiro, RJ, Brasil. Financiamento do CNPq e da FAPERJ.

Recebido em: 01/10/2016

Aprovado em: 27/11/2017 